\section{Fine Needle Aspiration Cytology and Intralesional Steroid Injection in a Central Giant Cell Granuloma Affecting the Gingiva: A New Clinical Approach}

Felipe Paiva Fonseca, Ana Carolina Prado Ribeiro, Alan Roger dos SantosSilva, Pablo Agustin Vargas, Márcio Ajudarte Lopes
Department of Oral Diagnosis, Piracicaba School of Dentistry, UNICAMP - University of Campinas, Piracicaba, SP, Brazil

Correspondence: Prof. Dr. Márcio Ajudarte Lopes, Avenida Limeira, 901, 13414-903 Piracicaba, SP, Brasil. Tel.: +55-19-2106-5320. e-mail: malopes@fop.unicamp.br
Central giant cell granuloma (CGCG) is a benign jaw lesion predominantly found in the mandible of young female patients with a variable clinical behavior. Although surgical management is regarded as the main treatment modality for this lesion, the use of intralesional injections of steroids has been recently advocated for its treatment. In addition to this conservative management, the use of fine needle aspiration cytology (FNAC) for diagnosing CGCGs has been proven a safe and efficient approach, especially useful in cases with lesions located in esthetic regions. Herein, it is described a case of CGCG extending to the overlying gingiva of a 15-year-old male patient diagnosed by FNAC and subsequently treated with intralesional injections of a solution of triamcinolone acetonide and ethanolamine oleate that led to an important clinical remission, allowing a more conservative surgical procedure for preservation of gingival esthetics. Therefore, both procedures can be considered as management options for CGCG of the jaws.
Key Words: ethanolamine oleate, fine needle aspiration cytology, giant cell granuloma, triamcinolone.

\section{Introduction}

Gingival reddish lesions account for an important number of disorders frequently diagnosed in the regular dental practice and central giant cell granuloma (CGCG) represents one of the main entities of this group. CGCG is defined by the World Health Organization as a nonneoplastic condition that consists of cellular fibrous tissue containing multiple foci of hemorrhage, aggregations of multinucleated giant cells and occasional trabeculae of bone (1-3). The lesion is predominantly found in young adults before the age of 30 years with a female preponderance. The anterior portion of the mandible is the most frequently affected region, commonly extending across the midline (4).

Although the regular histopathological evaluation of this lesion does not pose difficulties for its correct diagnosis, the use of fine-needle aspiration cytology (FNAC) for the primary diagnosis of CGCG has been advocated, since this method has been proven safe and efficient, causing less injury to the patient, what is especially important for pediatric patients and cases of lesions located in esthetic regions (5-7). In addition, the conventional surgical management of CGCG usually causes major esthetic defects (2). Therefore, the intralesional injection of corticosteroids represents an important alternative non-surgical approach for treating this condition and successful results have been reported (8-10).

This paper presents the case of a young patient who had a CGCG diagnosed by FNAC and subsequently underwent intralesional injections of triamcinolone acetonide for treatment, emphasizing the usefulness and importance of both techniques for the management of CGCG of the jaws.

\section{Case Report}

A 15-year-old male patient was referred to our department by his dentist for evaluation of a reddish lesion in the gingiva. Extraoral examination revealed no facial asymmetry, swelling or regional lymphadenopathy. Intra-orally, a reddish-purple lesion involving both the attached and marginal gingiva was noted between the mandibular right lateral incisor and canine (Fig. $1 \mathrm{~A}$ and 1B). Panoramic and periapical $x$-rays were carried out and showed a well-circumscribed radiolucent lesion in the affected region (Fig. 2).

Conventional biopsy was avoided due to the involvement of the marginal gingiva, and FNAC was performed. The material obtained was spread on glass slides. Three of them were immediately air fixed for Diff-Quik staining and other two slides were fixed in 95\% ethanol for Papanicolaou staining. Cytological smears revealed the presence of multinucleated giant cells immersed in a hemorrhagic background with scattered neutrophils, establishing the diagnosis of CGCG (Fig. 3A and 3B). Laboratory values of serum calcium, alkaline phosphates, phosphorous and parathyroid hormone were within normal limits, ruling out 
primary hyperparathyroidism.

Because of the location of the lesion and the possible periodontal defects that could arise as a result of the surgery, the corticosteroid intralesional injection treatment was proposed to the patient and his parents with the understanding that surgery was left as an option if the steroid treatment could not achieve the expected outcome.

Treatment comprised 6 administrations of intralesional corticosteroid injections. The first application consisted of a mixture of triamcinolone acetonide (Theracort $40 \mathrm{mg} / \mathrm{mL}$; Theraskin Farmacêutica Ltda., São Bernardo do Campo, SP, Brazil) and 2\% lidocaine with 1:200,000 epinephrine (mixed in a 1:1 ratio) with total volume of $0.3 \mathrm{~mL}$. As a significant bleeding was observed during the injection, it was decided to add ethanolamine oleate (mixed in a 1:1 ratio with triamcinolone acetonide) using the same $0.3 \mathrm{~mL}$ of total volume in the next injection. The second application was performed after 21 days and the following two injections also had the same interval between each other. The fifth injection was performed after 1 month and the last one 2 months later (Fig. 4A). A decrease in size and color was noticed after every each injection. Although following the fifth injection clinical changes were less evident, the lesion did not involve the marginal gingiva. At this time, it was decided to keep the patient under systematic follow-up (Fig. 4B).

Interestingly, despite important clinical improvement, no radiographic changes were observed. Therefore, after approximately 2 years of follow-up with stable clinical and radiographic aspects, a surgical removal was planned. Computed tomography was obtained and showed in more details an intraosseous and well-circumscribed hypodense lesion. Surgical curettage was performed preserving the marginal gingiva. The histological evaluation revealed the presence of a thick band of collagenous tissue and deposition of hemossiderin beneath the overlying normal epithelium. Deeper in the connective tissue there were aggregations of multinucleated giant cells distributed in a cellular fibrous tissue containing multiple foci of hemorrhage and occasional trabeculae of bone confirming the diagnosis of CGCG (Fig. 5).

The patient is in post-operative follow-up for 30 months without evidence of recurrence or periodontal defects (Fig. 6).

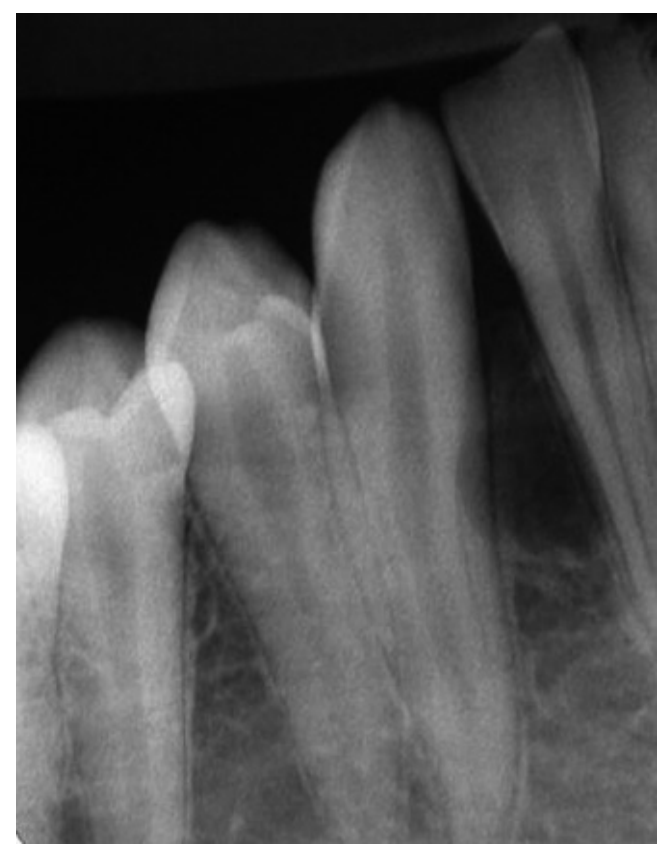

Figure 2. Periapical radiograph revealing a radiolucent lesion between the mandibular right lateral incisor and canine.
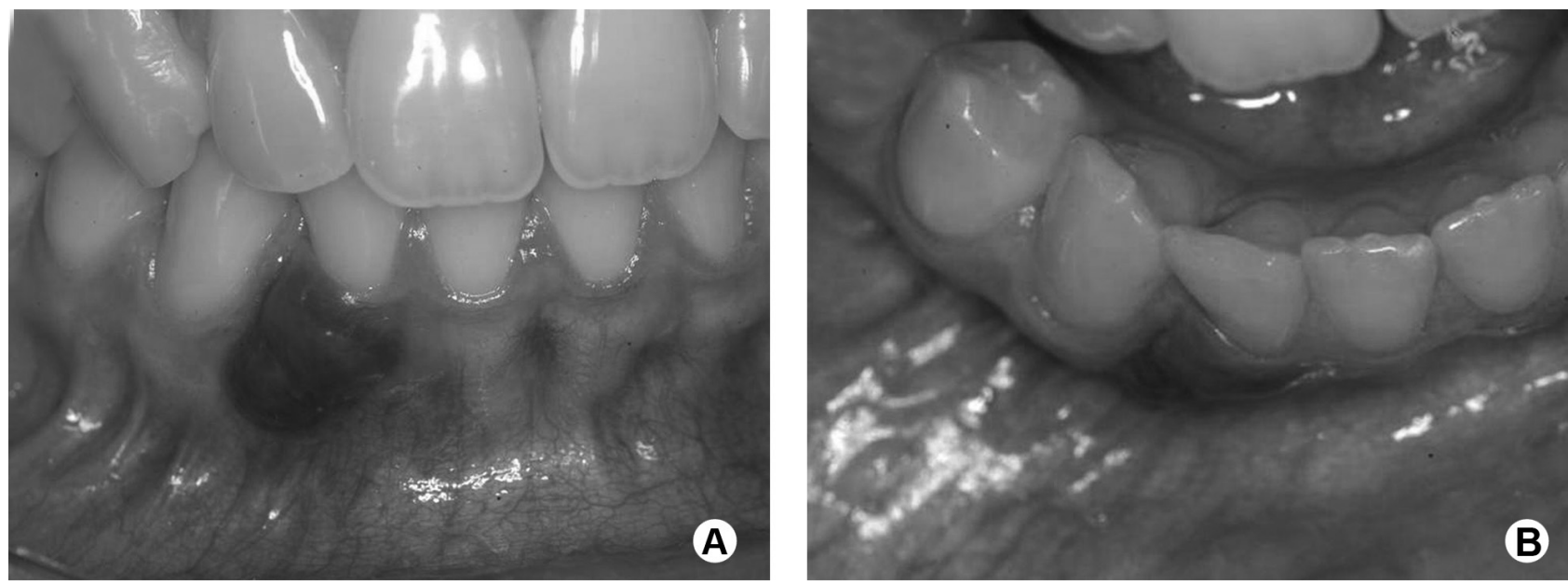

Figure 1. Reddish-purple lesion involving both the attached and marginal gingiva between the mandibular right lateral incisor and canine. A: Frontal view. B: Oclusal view. 

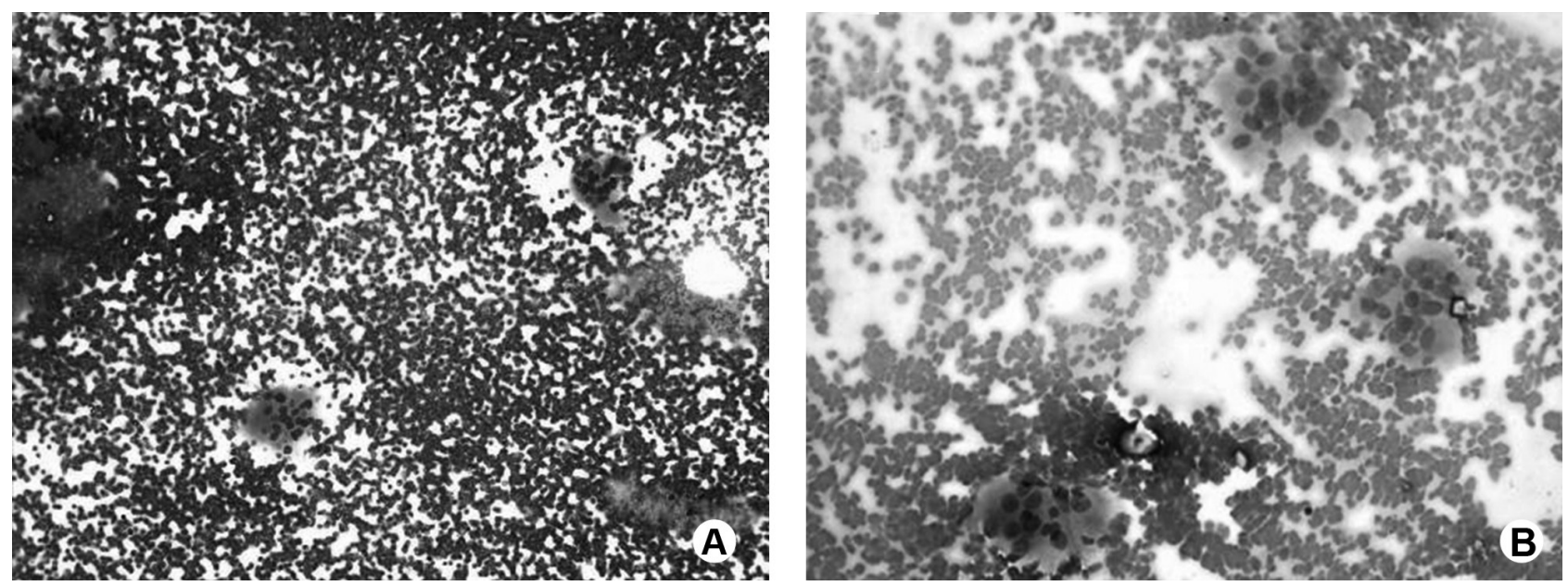

Figure 3. Cytological features showing the presence of numerous multinucleated giant cells immersed in a hemorrhagic background with scattered neutrophils. A: Diff-Quik staining (100x). B: Papanicolaou staining (100x).
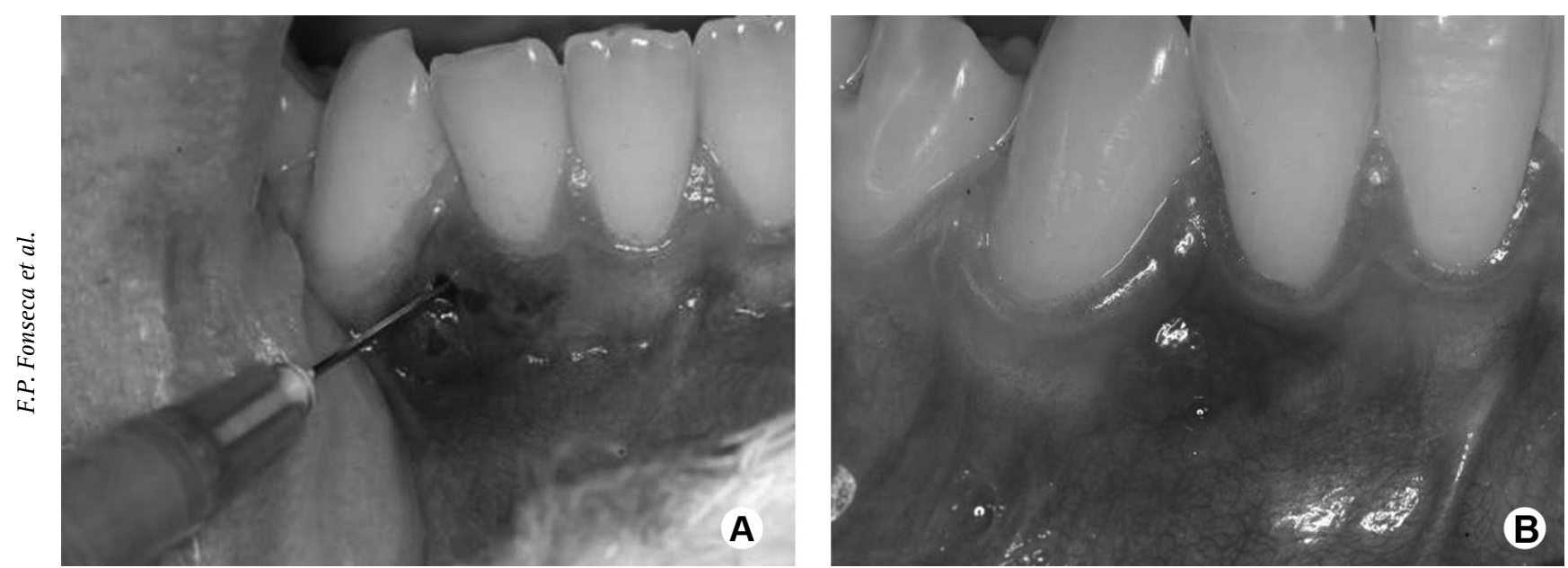

Figure 4. Composite figure of clinical images. A: Intralesional corticosteroid injection. B: Clinical appearance of the region after the sixth injection, revealing the marginal gingiva free of lesion.

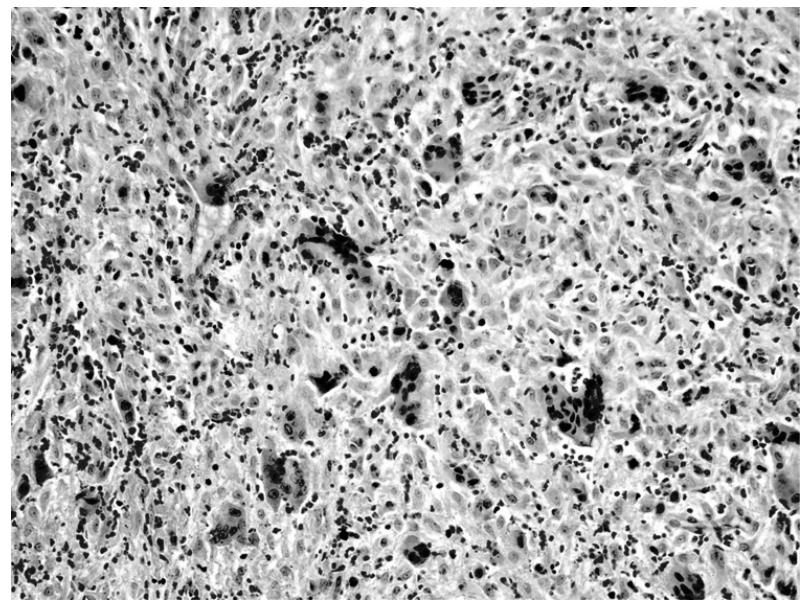

Figure 5. Histopathological exam revealing aggregations of multinucleated giant cells distributed in a cellular fibrous tissue containing multiple foci of hemorrhage (Hematoxylin and eosin; 100x).

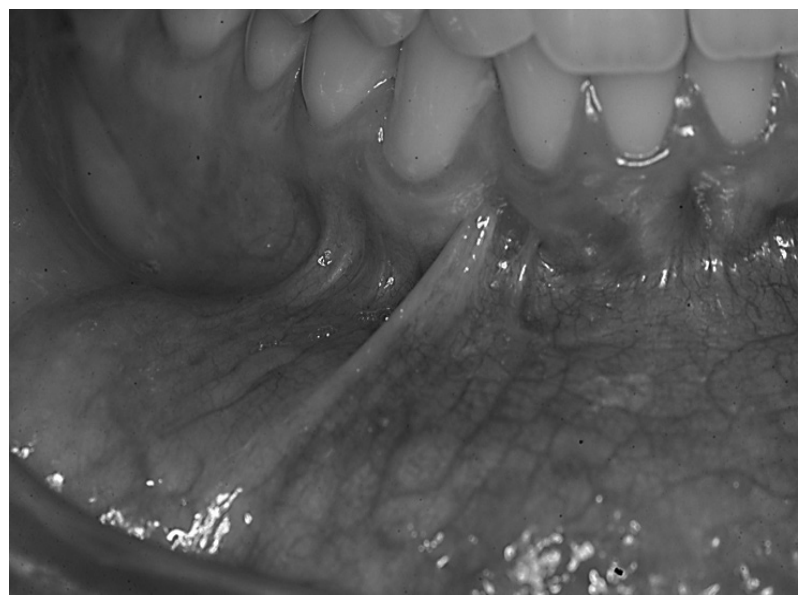

Figure 6. Clinical aspect of the affected region 30 months after the surgery, showing complete recovery with no evidence of recurrence or periodontal defects. 


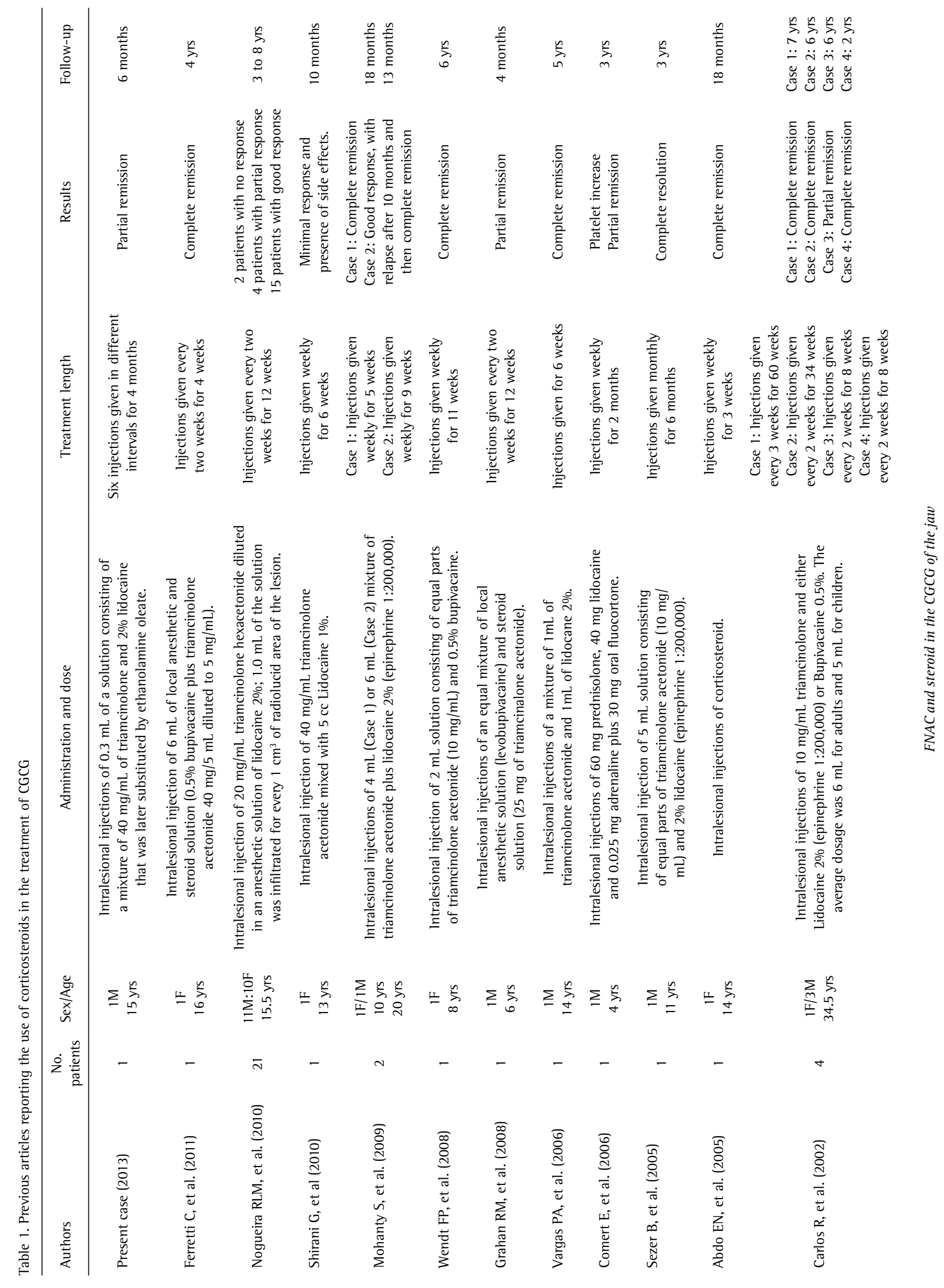




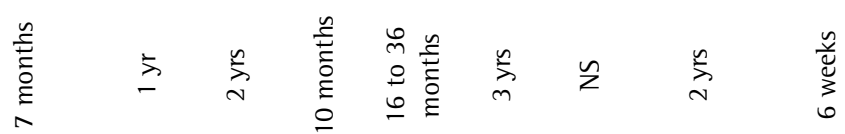
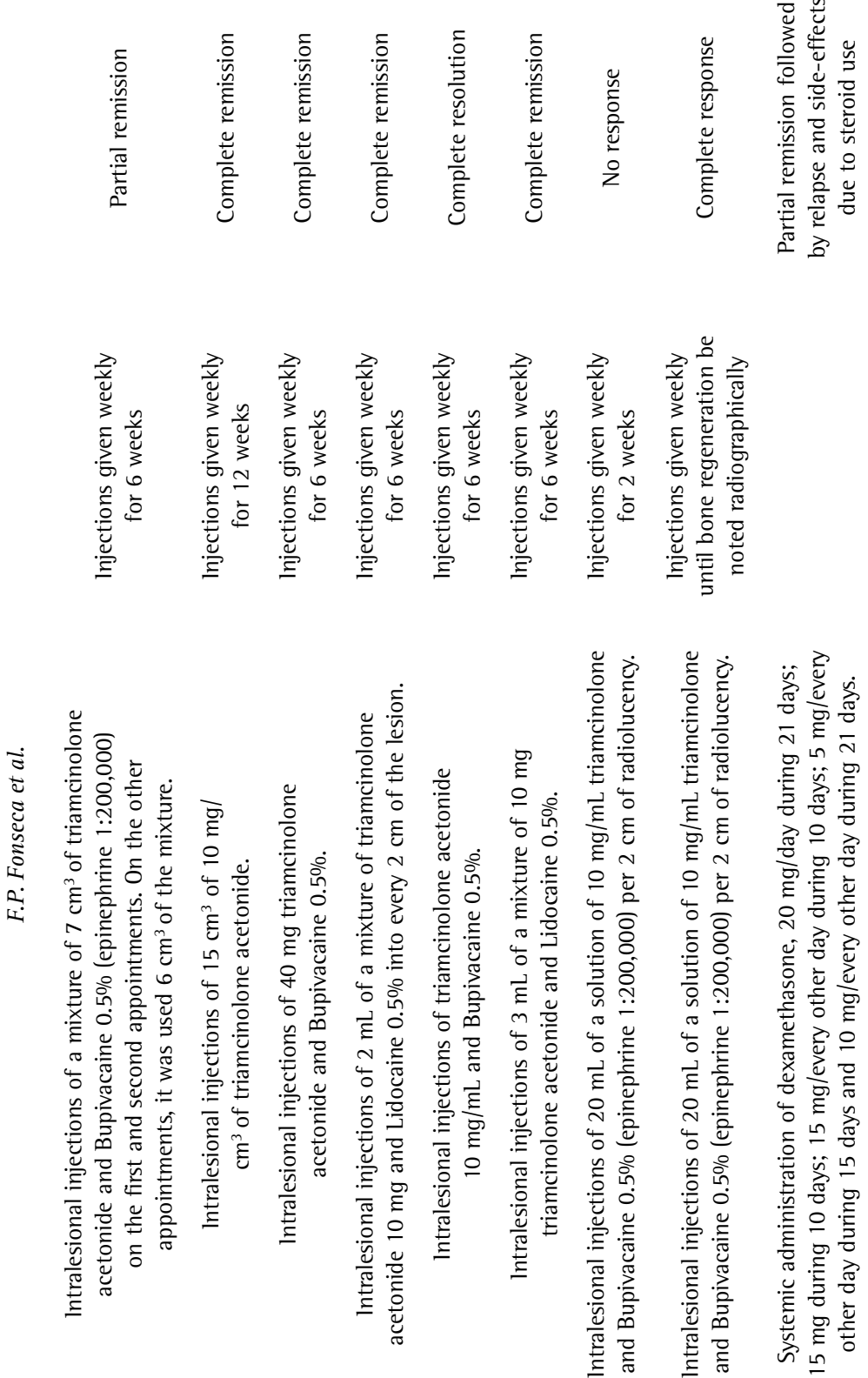

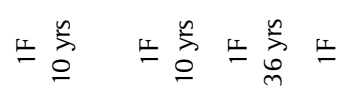
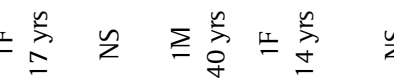

$\sum \sum_{\hat{n}}^{n}$

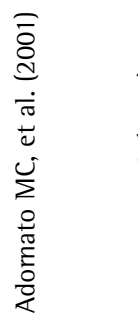

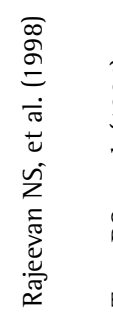

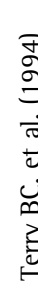

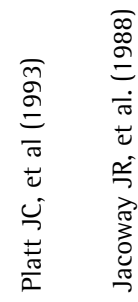

\section{Discussion}

Reddish nodular lesions affecting the gingival tissue of young patients may be easily found in the clinical practice. The lack of an adequate oral hygiene commonly leads to the development of non-neoplastic proliferative disorders, such as pyogenic granuloma and peripheral ossifying fibroma (POF), which normally manifest as asymptomatic nodules in the interpapillary and gingival regions. However, a more reddish to purplish appearance with an increased bleeding rate and areas of ulceration are expected to be seen in pyogenic granuloma if compared to the more fibrotic POF. Moreover, peripheral giant cell granuloma (PGCG) would be another important diagnostic possibility to be considered when a general practitioner is facing a reddish gingival lesion. As exemplified in the present case, however, radiographic examination is mandatory to distinct PGCG from its central counterpart, highlighting the importance of radiographic evaluation in cases of lesions involving the gingival tissue. Vascular disorders like hemangioma could also be considered in these circumstances and a careful clinical approach would be advisable in these cases avoiding conventional biopsy.

Considering the radiographic aspects, by facing a radiolucent image in a dental area, it is important to evaluate its relationship to adjacent teeth, dental vitality, presence of lamina dura, root resorption and root displacement in order to lead the diagnosis process to inflammatory radicular lesions or to a more aggressive entity. In the current case, the radiolucency was found in the alveolar crest between two vital teeth and the lamina dura was preserved excluding the possibility of inflammatory lesion associated to pulp necrosis. Similarly, no signs of root resorption or root displacement could be identified suggesting a more indolent clinical behavior. Hence, considering the clinical and radiographic features, and the good oral hygiene status of the patient, CGCG was raised as the main hypothesis.

CGCG was first described in 1953 (11) and due to its broadly variable clinical behavior, ranging from an asymptomatic 


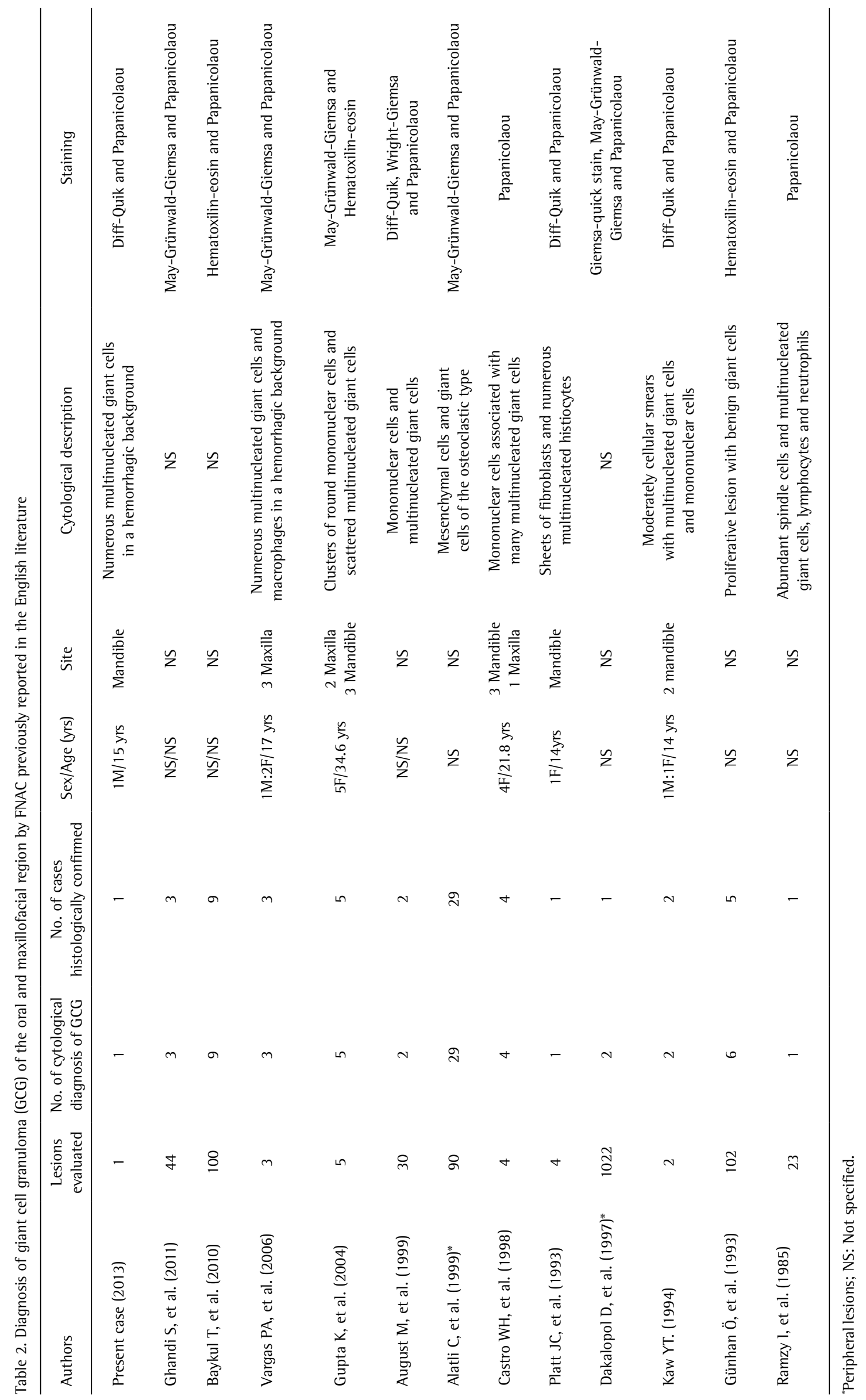


slow-growing swelling to an aggressive lesion, the surgical approach has been regarded as the treatment of choice for this lesion, which may vary from curettage to en bloc resection. Therefore, both the destructive properties of the lesion and its aggressive management can result in significant functional and esthetic defects, what is particularly a concern in pediatric and young adult patients $(12,13)$.

In the last years, different nonsurgical treatments have been proposed. Systemic calcitonin, interferon 2-alpha and intralesional corticosteroids have shown varying degrees of success and reduced the necessity of major surgical procedures $(9,14,15)$. The use of steroids for treating CGCGs was first suggested in 1981; however, their systemic administration had to be stopped because of important side effects (16). So, the use of intralesional injections of steroids was proposed, what led to higher tissue concentration and smaller side effects (17). The satisfactory results obtained using intralesional injection of steroids in the treatment of CGCGs may be due to both the inhibition of the extracellular production of lysosomal proteases by multinucleated giant cells and to the steroidal apoptotic action on osteoclast-like cells (2).

In 1994 a protocol for treatment of CGCGs of the jaws using a weekly intralesional injection of a mixture of triamcinolone acetonide and a local anesthetic (marcaine $0.5 \%$ with epinephrine $1: 200,000$ ), mixed in equal parts and given for at least 6 weeks was published (15) and thereafter it has been used by different authors that implemented several alterations not only in the dosage and type of drugs, but also in the duration, interval between injections and the number of applications used (Table 1). Although few authors have observed no or minimal decrease of the lesion following the use of intralesional steroid injections $(18,19)$, the majority of the studies has reported complete resolutions, which it is well illustrated in the only clinical series published that revealed excellent results with the use of intralesional steroids in the treatment of CGCGs (9).

In the present case, the lesion extended to the overlying soft tissue and involved both the attached and marginal gingiva. Although surgery would completely remove the lesion, this procedure would cause periodontal defect. Therefore, in order to avoid or minimize periodontal sequelae, we opted for using the above-mentioned protocol of intralesional injection of corticosteroid, with the exception of changing $0.5 \%$ bupivacaine by $2 \%$ lidocaine. However, after the second injection, we decided to remove the anesthetic solution and add the sclerosing agent ethanolamine oleate in a 1:1 ratio because it was assumed that its sclerosing action would improve the results due to the extensive vascular component present in CGCGs. To the best of our knowledge, this is the first paper reporting the use of ethanolamine oleate in conjunction to triamcinolone for treating CGCG. It is important to emphasize that, although a complete remission was not observed, the main objective was reached, which was reducing the lesion size to permit a more conservative surgical procedure that could preserve the marginal gingiva. Although a satisfactory result was obtained in this case, further studies are necessary to evaluate the usefulness of ethanolamine oleate in combination with corticosteroid for the treatment of CGCGs.

In addition to the conservative treatment modality used in this case, we also opted for a non-invasive diagnostic approach. Thus, FNAC was performed for the diagnosis of CGCG. The role of this simple technique in the diagnosis of oral and maxillofacial lesions has increased dramatically in the last years especially because of its proven safety, accuracy and cost-effectiveness (20-23). Reviewing the English-language literature it is possible to find out several articles describing the value of FNAC in the diagnosis of oral and maxillofacial lesions and evaluating its efficacy in the diagnosis of giant cell lesions of the jaws (5-7). Taken together, the results obtained by these previous studies revealed a very high specificity and sensitivity of the cytological exam for diagnosing CGCG (Table 2). The aspirates obtained in the current case clearly revealed the typical presence of numerous multinucleated giant cells immersed in a bloody background, what is in accordance to the cases previously reported. Hence, the cytological features obtained in cases suspected of CGCG taken together with clinical, laboratory and imaging findings, easily allows the correct diagnosis of CGCG, reinforcing the usefulness of this approach in the identification of lesions affecting the oral and maxillofacial region.

Based on the current report and the satisfactory results consistently reported by different authors regarding the usefulness of intralesional injection of corticosteroid as a non-invasive treatment modality for CGCG and considering the accuracy and reliability of FNAC for its diagnosis, it is expected that both procedures will play an important role in the management of this lesion in the future, becoming an option for management of CGCG affecting the jaws.

\section{Resumo}

0 granuloma central de células gigantes (GCCG) é uma lesão benigna dos maxilares predominantemente encontrada na mandibula de pacientes jovens do sexo feminino com um variado comportamento clínico. Apesar de o manejo cirúrgico representar a principal modalidade terapêutica para esta lesão, o uso de injeções intralesionais de esteróides tem sido recentemente proposto para seu tratamento. Além do manejo conservador, o uso da punção aspirativa por agulha fina (PAAF) para o diagnóstico do GCCG tem sido comprovado ser uma abordagem segura e eficiente, especialmente útil em casos de lesões localizadas em regiões estéticas. Descrevemos aqui um caso de GCCG estendendo-se para a gengiva adjacente em um paciente do sexo masculino, 15 anos de idade, 
diagnosticado por meio da PAAFe subsequentemente tratado com injeções intralesionais de uma solução de acetato de triancinolona e oleato de etanolamina que levou a uma importante remissão clínica, permitindo a realização de uma abordagem cirúrgica conservadora preservando a estética periodontal. Por este motivo, ambos os procedimentos podem ser considerados opções de manejo para o GCCG dos maxilares.

\section{References}

1. Adornato $M C$, Paticoff KA. Intralesional corticosteroid injection for treatment of central giant-cell granuloma. J Am Dent Assoc 2001;132:186-190.

2. Ferretti $C$, Muthray E. Management of central giant cell granuloma of mandible using intralesional corticosteroids: case report and review of the literature. J Oral Maxillofac Surg 2011;69:2824-2829.

3. Jundt G. WHO Histological Classification of odontogenic tumors. Bonerelated lesions. In: Pathology and genetics of tumors of the head and neck. WHO. Lyon: IARC Press;2005. p 324.

4. Amaral FR, Gomes CC, Oliveira CS, Souza PEA, Gomez RS. Clonality analysis of giant cell lesion of the jaws. Braz Dent J 2010;21:361-364.

5. Vargas PA, Prado FO, Fregnani ER, Perez DEC, Lopes MA, Moraes M, et al.. Fine needle aspiration biopsy in central giant cell lesion. A report of 3 cases. Acta Cytol 2006;50:449-454.

6. Castro WH, Filho ECS, Souza PEA, Gomez RS. Immunocytochemistry of fine needle aspirates from central giant cell granuloma. $\mathrm{Br} J$ Oral Maxillofac Surg 1998;36:301-303.

7. Kaw YT. Fine needle aspiration cytology of central giant cell granuloma of the jaw. A report of two cases. Acta Cytol 1994;38:475-478.

8. Carlos R, Sedano HO. Intralesional corticosteroids as an alternative treatment for central giant cell granuloma. Oral Surg Oral Med Oral Pathol Oral Radiol Endod 2002;93:161-166.

9. Nogueira RLM, Teixeira RC, Cavalcante RB, Ribeiro RA, Rabenhosrt SHB. Intralesional injection of triamcinolone hexacetonide as an alternative treatment for central giant-cell granuloma in 21 cases. Int J OralMaxillofac Surg 2010;39:1204-1210.

10. Mohanty S, Jhamb A. Central giant cell lesion of mandible managed by intralesional triamcinolone injections. A report of two cases and literature review. Med Oral Patol Oral Cir Bucal 2009;14:E98-E102.

11. Jaffe HL. Giant-cell reparative granuloma, traumatic bone cyst, and fibrous (fibro-osseous) dysplasia of the jaw bones. Oral Surg 1953;6:159-175

12. Comert $E$, Turanli $M$, Ulu S. Oral and intralesional steroid therapy in giant cell granuloma. Acta Otolaryngol 2006;126:664-666.

13. Tosco $P$, Tanteri $G$, laquinta $C$, Fasolis $M$, Roccia $F$, Berrone $S$, et al.. Surgical treatment and reconstruction for central giant cell granuloma of the jaws: a review of 18 cases. J CranioMaxillofac Surg 2009;37:380387.

14. Borges HOI, Machado RA, Vidor MM, Beltrão RG, Heitz C, Filho MS. Calcitonin: a non-invasive giant cells therapy. Int J Pediat Otorhinolaryngol 2008;72:959-963.

15. Terry BC, Jacoway JR. Management of central giant cell lesions: an alternative to surgical therapy. Oral Maxillofac Surg Clin N Am 1994;6:579-601.

16. Body JJ, Jortay AM, de Jager R, Ardichvili D. Treatment with steroids of a giant cell granuloma of the maxilla. J Surg Oncol 1981;16:7-13.

17. Jacoway JR, Howell FV, Terry BC. Central giant cell granuloma - an alternative to surgical therapy. Oral Surg Oral Med Oral Pathol 1988;66:572.

18. Platt JC, Rodgers SF, Davidson D, Nelson CL. Fine-needle aspiration biopsy in oral and maxillofacial surgery. Oral Surg Oral Med Oral Pathol 1993;75:152-155.

19. Shirani G, Abbasi AJ, Mohebbi SZ, Shirinbak I. Management of a locally invasive Central Giant Cell Granuloma (CGCL) of mandible: report of an extraordinary large case. J Craniomaxillofac Surg 2011;39:530-533.

20. Gandhi S, Lata J, Gandhi N. Fine needle aspiration cytology: a diagnostic aid for oral lesions. J Oral Maxillofac Surg 2011;69:16681677.

21. Nai GA, Grosso RN. Fine-needle aspiration biopsy of ameloblastic carcinoma of the mandible: a case report. Braz Dent J 2011;22:254-257.

22. Olekar ST, Sangeeta T, Kumar YS, Gururaj M. Diagnostic reliability of fine needle aspiration cytology against histopathology for the diagnosis of oral squamous cell carcinoma and oral leukoplakia. J Contemp Dent Pract 2012;3:545-549.

23. Pektas ZO, Gunhan 0. Cytologically diagnosed metastatic small cell lung carcinoma in the mandibular soft tissue. Saudi Med J 2013;34:539-541.

Received April 9, 2013 Accepted July 6, 2013 